\title{
ANALISA TOTAL BAKTERI PADA IKAN TUNA ASAP YANG DIRENDAM DENGAN ASAP CAIR "WAA SAGU" SELAMA PENYIMPANAN PADA SUHU KAMAR
}

\author{
Esterlina E. E. M. Nanlohy \\ Program Studi Teknologi Hasil Perikanan, FPIK Unpatti Ambon \\ E-mail: esterlina_nanlohy@yahoo.co.id
}

\begin{abstract}
Backgroud: During this traditional way of preserving fish is usually done by fumigation but is now developed another preservation method that uses liquid smoke method.

Method: Liquid smokes used in this study are from the liquid smoke "waa sago" with concentration $5 \%$ $+\mathrm{NaCl} 5 \%$, soaked 10 minute, the type of fish used tuna (Thunus sp). Meat tuna soaked in liquid smoke and stored for 10 days at room temperature. This study aimed to determine the microbiological quality (total plate count), soaked smoked tuna with liquid smoke "waa sago" during storage at room temperature.

Result: Results of analysis of total bacteria in smoked tuna still eligible SNI and safe and suitable for consumption. Liquid smoke "waa sago" can extend the shelf life of tuna fish for 10 days at room temperature. Liquid smoke has antibacterial properties more easily applied and more secure than conventional smoke and tar fraction containing aromatic hydrocarbons have been separated, so that the products are free polutean liquid smoke and carcinogens.

Conclusion: Total bacteria in tuna, marinated with liquid smoke waa sago stored for 10 days, still meets ISO standards. Liquid smoke from sago waa potential as an antibacterial because it can maintain the quality of smoked tuna microbiologically during storage at room temperature.
\end{abstract}

Key word: total plate count, tuna fish, liquid smoke, waa sago

\begin{abstract}
Abstrak
Latar Belakang: Selama ini cara pengawetan ikan tradisonal biasanya dilakukan dengan tetapi saat ini sudah dikembangkan metode pengawetan lain yaitu menggunakan metode pengasapan asap cair. Metode: Asap cair yang digunakan dalam penelitian ini adalah asap cair dari "waa sagu" dengan konsentrasi $5 \%$ + garam 5\% dan direndam selama 10 menit, jenis ikan yang digunakan yakni ikan tuna (Thunus sp). Daging ikan tuna direndam dalam asap cair dan disimpan selama 10 hari pada suhu kamar. Penelitian ini bertujuan untuk untuk mengetahui mutu mikrobiologis (total plate count) ikan tuna asap yang direndam dengan asap cair "waa sagu" selama penyimpanan suhu kamar.

Hasil: Hasil analisa total bakteri pada ikan tuna asap masih memenuhi syarat SNI serta aman dan layak untuk dikonsumsi. Asap cair dari "waa sagu" dapat memperpanjang masa simpan ikan tuna selama 10 hari pada suhu kamar. Asap cair mempunyai sifat antibakteri lebih mudah diaplikasikan dan lebih aman dari asap konvensional dan fraksi tar yang mengandung hidrokarbon aromatik telah dipisahkan, sehingga produk asap cair bebas polutean dan karsinogen.

Kesimpulan: Total bakteri pada ikan tuna yang direndam dengan asap cair 'waa sagu yang disimpan selama 10 hari, masih memenuhi standar SNI. Asap cair dari waa sagu berpotensi sebagai antibakteri karena dapat mempertahankan mutu ikan tuna asap secara mikrobiologis selama penyimpanan pada suhu kamar.
\end{abstract}

Kata Kunci: total koloni bakteri, ikan tuna, asap cair, waa sagu 


\section{PENDAHULUAN}

Ikan merupakan salah satu sumber makanan yang sangat dibutuhkan oleh manusia karena banyak mengandung protein. Kandungan protein dan air yang cukup tinggi, ikan termasuk komoditi yang sangat mudah busuk. Oleh karena itu, diperlukan upaya untuk menghambat proses pembusukan dengan cara pengawetan dan pengolahan. Salah satu cara pengolahan ialah dengan pengasapan (Afrianto dan Liviawaty, 1989). Pengasapan merupakan suatu cara pengolahan atau pengawetan dengan memanfaatkan kombinasi perlakuan pengeringan dan pemberian senyawa kimia dari hasil pembakaran bahan bakar alami (Wibowo, 2002). Winarno (1993), menyatakan bahwa pengasapan ikan adalah teknik melekatnya dan memasukkan berbagai senyawa kimia ke dalam tubuh ikan.

Pengasapan cair merupakan salah satu metode yang dapat digunakan untuk dapat membandingkan antara produk ikan asap yang dihasilkan dari pengasapan tradisional. Dengan metode pengasapan cair akan dapat dilakukan modifikasi proses penerapan suhu pengeringan atau pengovenan sehingga sehingga kadar air produk yang dihasilkan dapat lebih rendah yang berdampak pada daya simpan yang lebih lama. Selain itu juga dapat dilakukan percobaan mengenai perbedaan perlakuan terhadap konsentrasi asap cair yang digunakan dalam pengasapan cair, sehingga dapat lebih meminimalisasi senyawa-senyawa Hidrokkarbon Aromatik Polisiklik (HAP) pada produk yang dihasilkan. Pengasapan cair dilakukan dengan menggunakan liguid smoke yang diproduksi melalui cara pirolisis pada "waa sagu" kemudian diikuti dengan peristiwa kondensasi dalam kondensor berpendingin air. Liquid smoke yang dihasilkan dimurnikan dengan mengalirkannnya melalui kolom zeolit, kemudian diencerkan.

Penggunaan asap cair terutama dikaitkan dengan siat-sifat fungsional asap cair, diantaranya adalah sebagai antioksidan, antibakteri, antijamur dan potensinya dalam pembentukan warna coklat pada produk (Maga, 1987). Asap cair dapat diaplikasikan pada berbagai bahan pangan karena dapat berperan dalam pengawetan bahan pangan, selama ini cara pengawetan tradisonal ikan biasanya dilakukan dengan pengasapan. Saat ini sudah dikembangkan metode pengawetan yang lain yaitu menggunakan metode pengasapan asap cair dengan mencelupkan bahan pada larutan asap atau menyemprotkan larutan asap pada bahan pangan, kemudian produk dikeringkan.

Menurut Gorbatov et al., (1971) dan Maga (1987) beberapa kelemahan pengasapan tradisional antara lain: flavor dan konsentrasi konstituen asap tidak seragam, waktu dan suhu tidak sama, sehingga produk yang dihasilkan tidak seragam serta kemungkinan terbentuknya senyawa Hidrokarbon Aromatik Polisiklik (benzo(a)piren) yang bersifat karsinogenik. Eklund et al (1982), mengemukakan bahwa asap cair lebih mudah diaplikasikan karena konsentrasinya dapat dikontrol agar memberikan flavor dan warna yang seragam. Selanjutnya dikatakan bahwa asap cair telah disetujui oleh banyak negara untuk digunakan pada pangan dan sekarang ini banyak digunakan dalam "comminuted" produk daging, selain itu asap cair tidak menunjukkan karsinogenik atau sifat-sifat toksik lain pada pengujian standar. Hal ini didukung oleh pernyataan Hollenbeck (1978), bahwa asap cair mempunyai sifat antibakteri lebih mudah diaplikasikan dan lebih aman dari asap konvensional dan fraksi tar yang mengandung hidrokarbon aromatik telah dipisahkan, sehingga produk asap cair bebas polutean dan karsinogen. Sedangkan menurut Giese (1991), sanitasi pada pengolahan juga sangat mempengaruhi kualitas produk akhir suatu bahan.

Berdasarkan alasan-alasan tersebut di atas, maka dilakukan penelitian ini untuk mengetahui mutu mikrobiologis (total plate count) ikan tuna asap yang direndam dengan asap cair "waa sagu" selama penyimpanan suhu kamar.

\section{MATERI DAN METODE Bahan dan Alat}

Bahan baku yang digunakan pada penelitian ini adalah ikan tuna (Thunnus sp.) segar, asap cair dari waa sagu, air tawar untuk pencucian. Bahan yang digunakan untuk analisa laboratorium adalah Plate 
Counte Agar (PCA), NaCl 0,9\%, aquades, aluminium foil, alkohol $70 \%$ dan $90 \%$.

Peralatan yang digunakan yaitu wadah untuk mencuci ikan, oven untuk proses pengasapan. Sedangkan peralatan untuk uji mikrobiologis yaitu autoclave, cawan petri, inkubator, timbangan analitik, tabung reaksi, oven pengering, pipet, lampu spritus, labu Erlenmeyer.

\section{Tata Laksana Penelitian}

Analisis mikrobiologis: analisis total bakteri (Total Plate Count).

Prosedur perhitungan jumlah bakteri menurut modifikasi Fardiaz (1993) sebagai berikut:

1. Semua peralatan disterilkan dengan menggunakan autoclave pada tekanan 15 psi selam 15 menit pada suhu $121^{\circ} \mathrm{C}$.

2. Ditimbang media PCA, kemudian dimasukkan ke dalam Erlenmeyer dan diberi aquades sebanyak $250 \mathrm{ml}$ setelah itu dihomogenkan dengan magnet putar. $\mathrm{pH}$ media diatur pada $\mathrm{pH} 7,0$, selanjutnya direbus sampai agar larut dan disterilkan dengan autoclave pada tekanan 15 psi dengan suhu $121^{\circ} \mathrm{C}$ selama 15 menit.

3. Disiapkan larutan pengencer $0,9 \% \mathrm{NaCl}$, masing-masing untuk pengenceran tingkat pertama $90 \mathrm{ml}$ dan mulut Erlenmeyer ditutup dengan aluminium foil, sedangkan untuk tingkat pengenceran kedua dan ketiga masingmasing diambil $9 \mathrm{ml} \mathrm{NaCl} \mathrm{0,9 \%} \mathrm{kemudian}$ dimasukkan ke dalam tabung Hush yang dilengkapi dengan penutup. Semua larutan pengenceran disterilkan dengan autoclave pada suhu $121^{\circ} \mathrm{C}$ tekanan 15 psi selama 15 menit.

4. Sampel diblender dan timbang 10 gram secara aseptis kemudian dimasukkan ke dalam $90 \mathrm{ml} \mathrm{NaCl} \mathrm{0,9 \%} \mathrm{steril} \mathrm{sehingga}$ diperoleh larutan dengan tingkat pengenceran $10^{-1}$. Dari pengenceran $10^{-1}$ dipipet $1 \mathrm{ml}$ ke dalam tabung reaksi 2 kemudian dihomogenkan sehingga diperoleh pengenceran $10^{-2}$.

5. Dari setiap pengenceran diambil $1 \mathrm{ml}$ pindahkan ke cawan petri steril yang telah diberi kode untuk tiap sampel pada tingkat pengenceran tertentu.

6. Ke dalam semua cawan petri dituangkan secara aseptis PCA sebanyak $15 \mathrm{ml}$ - 20 $\mathrm{ml}$. Setelah penuangan, cawan petri digoyang perlahan-lahan sambil diputar 3 kali ke kiri, ke kanan, lalu ke depan, ke belakang, kiri dan kanan, kemudian didinginkan sampai agar mengeras. Setelah PCA padat dimasukkan ke dalam inkubator selama 24 jam pada suhu $35^{\circ} \mathrm{C}$

\section{Analisis Data}

Analisis data dilakukan secara deskriptif, data disajikan dalam bentuk tabel (histogram) dan gambar (potret).

\section{HASIL DAN PEMBAHASAN \\ Total Plate Count (TPC) Pada Ikan Tuna Asap}

Tabel 1. Nilai Rata-Rata TPC Pada Ikan Tuna Asap Selama Penyimpanan Pada Suhu Kamar (koloni/gram).

\begin{tabular}{cc}
\hline Lama penyimpanan (hari) & Nilai rata-rata TPC (cfu/gr) \\
\hline 0 & {$[5,0] \times 10^{1}$} \\
2 & {$[6,5] \times 10^{1}$} \\
4 & $3,3 \times 10^{2}$ \\
6 & $3,8 \times 10^{2}$ \\
8 & $4,3 \times 10^{2}$ \\
10 & $9,0 \times 10^{2}$ \\
\hline
\end{tabular}

Hasil pada tabel 1 dapat dilihat bahwa pada semakin lama waktu penyimpanan jumlah mikroba yang terdapat pada ikan tuna asap mengalami peningkatan selama penyimpanan dari $[5,0] \times 10^{1}$ (cfu/g) - 9,0 x $10^{2}$ (cfu/g). Tetapi jumlah mikroba yang terkandung pada ikan tuna asap yang diberi perlakukan perendaman asap cair masih di bawah zona aman konsumsi yakni $5 \times 10^{5}$ koloni/gram berdasarkan SNI 02-2725-1992 (BSN, 1992). Hasil ini menggambarkan bahwa di dalam asap cair mengandung senyawa bioaktif yang dapat berperan menekan pertumbuhan mikroba pada ikan 
tuna asap. Pertumbuhan koloni bakteri pada ikan tuna asap yang diinkubasi pada suhu $35^{\circ} \mathrm{C}$ selama 24 jam seperti yang ditampilkan pada pada gambar 1 .

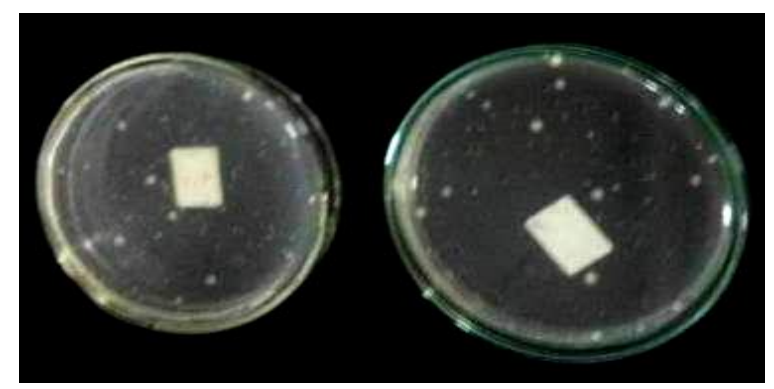

\section{Gambar 1. Koloni Bakteri Pada Ikan Tuna Asap Pada Media Plate Count Agar}

Efek antimikoba yang dihasilkan dari asap cair "waa sagu" selama proses pengasapan ikan tuna dimana selain pemanas dan pengeringan, ternyata yang paling utama yakni adanya senyawasenyawa kimia yang terkandung dalam asap seperti fenol, formaldehid, asam asetat dan kreosat yang menempel dibagian permukaan daging ikan tuna asap akan menghambat pembentukan spora dan pertumbuhan beberapa jenis bakteri dan jamur. Hal ini ditegaskan oleh Daun (1979) bahwa senyawa fenol dapat menghambat pertumbuhan bakteri dengan memperpanjang fase lage.

Peningkatan jumlah bakteri yang terkandung di dalam ikan tuna asap seperti yang ditunjukkan pada tabel 1, kemungkinkan dikarenakan sudah smakin menurunnya aktivitas dari fenol yang terdapat pada asap tersebut sehingga semakin banyaknya mikroba yang tumbuh. Faktor ini sangat didukung oleh adanya suhu penyimpanan yang sesuai untuk pertumbuhan mikroba yaitu suhu kamar $\left(37^{\circ} \mathrm{C}\right)$, sehingga akan memungkinkan mikroba tumbuh dengan baik.

Kenaikan jumlah mikroba pada ikan tuna asap hanya menunjukkan perbedaan yang tidak begitu besar. Karena perubahan ini hanya sedikit, hal ini menggambarkan bahwa walaupun bakteri tersebut bertambah jumlahnya namun sebenarnya bakteri sudah tidak mampu untuk tumbuh secara maksimal lagi. Selama kenaikan masih dalam kisaran kecil, ini lebih dimungkinkan oleh adanya sedikit perbedaan kondisi awal dari ikan sebelum diasapi. Walaupun ikan ditangkap pada waktu yang sama dengan menggunakan cara yang sama dan spesiesnya sama tidak menjamin bahwa pada saat itu ikan tersebut mempunyai jumlah bakteri yang sama. Kondisi awal dari ikan tuna inilah yang akan sangat menentukan terhadap proses selanjutnya. Namun pada penelitian ini semua ikan tuna yang diberi perlakuan perendaman dengan asap cair "waa sagu" dianggap kondisi yang sama, karena pengambilan sampel ini dilakukan pada tempat yang sama, waktu yang sama dan diproses dengan cara yang sama.

Hasil ini menggambarkan bahwa fenol dapat bekerja sebagai antiseptik, dimana mikroba tidak dapat tumbuh secara maksimal. Adapun cara kerja dari fenol menurut Daun (1979) adalah mengganggu metabolisme dari mikroba dengan menghambat pembentukan spora dari mikroba tersebut dan memperpanjang fase lage. Menurut Maga (1987), asap cair pada konsentrasi $6,5 \mathrm{~g} / \mathrm{kg}$, dapat memperpanjang fase lage Staphylococcus aureus $\left(10^{5}\right.$ $\mathrm{CFU} / \mathrm{ml}$ ) selama 4 hari pada konsentrasi 9,8 $\mathrm{g} / \mathrm{kg}$ adalah 14 hari.

Asap cair mempunyai berbagai sifat fungsional, seperti: untuk memberi aroma, rasa dan warna karena adanya senyawa fenol dan karbonil; sebagai bahanpengawet alami karena mengandung senyawa fenol dan asam yang berperan sebagai antibakteri dan antioksidan; sebagai bahan koagulan lateks pengganti asam format serta membantu pembentukan warna coklat pada produk. Berikut komponen-konponen penyusun asap cair meliputi:

1. Senyawa-senyawa fenol: senyawa fenol diduga berperan sebagai antioksidan 
sehingga dapat memperpanjang masa simpan produk asapan. Kandungan senyawa fenol dalam asap sangat tergantung pada temperatur pirolisis kayu. Menurut Girard (1992), kuantitas fenol pada katu sangat bervariasi yaitu antara 10-200 mg/kg. Beberapa jenis fenol yang biasanya terdapat dalam produk asapan adalah guaiakol dan siringol. Senyawa-senyawa fenol yang terdapat dalam asap kayu umumnya hidrokarbon aromatik yang tersusun dari cincin benzena dengan sejumlah gugus hidroksil yang terikat. Senyawa-senyawa fenol ini juga dapat mengikat gugusgugus lain seperti alhehid, keton, asam dan ester (Maga, 1998).

2. Senyawa-senyawa karbonil: senyawasenyawa karbonil dalam asap memiliki peranan pada pewarnaan dan citarasa produk asapan. Golongan senyawa ini mempunyai aroma seperti karamel yang unik. Jenis senyawa karbonil yang terdapat dalam asap cair antara lain vanilin dan siringaldehida.

3. Senyawa-senyawa asam: senyawasenyawa asam mempunyai peranan sebagai antibakteri dan membentuk citarasa produk asapan. Senyawa asam ini anatara lain adalah asam asetat, propionat, butirat dan valerat.

4. Senyawa hidrokarbon polisiklik aromatis: senyawa hidrokarbon polisiklisaromatis (HPA) dapat terbentuk pada proses pirolisis kayu. Senyawa hidrokarbon seperti benzo(a)pirena merupakan senyawa yang memiliki pengaruh buruk karena bersifat karsinogen, pembentukan berbagai senyawa HPA selama pembuatan asap tergantung dari beberapa hal, seperti temperatur pirolisis, waktu dan kelembaban udara pada proses pembuatan asap serta kandungan udara dalam kayu. Dikatakan juga bahwa semua proses yang menyebabkan terpisahnya partikelpartikel besar dari asap akan menurunkan kadar benzo(a)pirena. Proses tersebut antara lain adalah pengendapan dan penyaringan (Girard, 1992).

5. Senyawa benzo(a)pirena

Benzo(a)pirena mempunyai titik didih $310^{\circ} \mathrm{C}$ dan dapat menyebabkan kanker kulit jika dioleskan langsung pada permukaan kulit. Akan tetapi proses yang terjadi memerlukan waktu yang lama.

\section{KESIMPULAN}

Berdasarkan hasil penelitian maka dapat disimpulkan bahwa 1) total bakteri pada ikan tuna yang direndam dengan asap cair waa sagu yang disimpan selama 10 hari, masih memenuhi standar SNI dan 2) asap cair dari waa sagu berpotensi sebagai antibakteri karena dapat mempertahankan mutu ikan tuna asap secara mikrobiologis selama penyimpanan pada suhu kamar.

\section{DAFTAR PUSTAKA}

Afrianto dan Liviawaty, 1989. Pengawetan Dan Pengolahan Ikan. Kanisius. Yogyakarta

BSN, 1992. Petunjuk Pengujian Organoleptik Produk Perikanan. SNI) 12346-1991. Badan Standarisasi Nasional. Jakarta. Indonesia.

Daun, H. 1979. Interaction of Wood Smoke Component and Foods. Food Technol. 5 66-83

Eklund, M. W., G.A. Pelroy, Paranjpje., M.E Peterson and F.M Tenny. 1982. Inhibitor Of Clostridium botulinum Types A dan B Toxin Production Ny Liquid Smoke An Nacl In Hot-Process Smoke-Flavoried Fish. J. Food Protec. 45 (10).935-941.

Fardiaz, Srikandi. 1993. Analisis Mikrobiologi Pangan. PT Raja Grafindon Persada. Jakarta.

Giese, J.H.1991. Sanitation. The Key to food safety and Public Health. Food Technology.

Girard, J.P.1992. Smoking In Technology of Meat and Meat Products. Ed. Ellis Horwood. New York.

Gorbatov V.M., N.N. Krylova, V.P. Volovinskaya, Yu. N. Lyaskovskaya, K.L.Bazarova, R.I Khlamova and G. Yayakovleva. 1971. Liquid Smoke for Use in Cured Meats. Food Technologi 25 (1): 71-77.

Hollenbeck, C.M.1978. Summaries of Aldition Paper on Smoke Curing. The Symposium Smoke Curing-Advences in Theory of Food Tech. Dallas. Tex June 4-7, 1978. 
Biopendix, Volume 1, Nomor 1, Oktober 2014, hlm. 43-48

Maga, J.A., 1998.Smoke in Food Processing. CRD PRESS. FLORIDA. Wibowo, S. 2002. Industri Pengasapan Ikan. Penebar Swadaya. Yogyakarta.
Winarno, F.G dan S. Fardiaz, 1983. Dasar Teknologi Pangan. Departemen Teknologi Hasil Pertanian. Fatemeta. Institut Pertanian Bogor. Bogor. 